ZOOLOGIA 27 (3): 377-386, June, 2010

doi: $10.1590 /$ S1984-46702010000300009

\title{
Seasonal variation of macromedusae (Cnidaria) at North Bay, Florianópolis, southern Brazil
}

\author{
Miodeli Nogueira Júnior; Renato Mitsuo Nagata \& Maria Angélica Haddad
}

Programa de Pós Graduação em Zoologia, Departamento de Zoologia, Universidade Federal do Paraná. Centro Politécnico, Caixa Postal 19020, 81531-980 Curitiba, Paraná, Brazil.

E-mail:miodeli@gmail.com; mahaddad@ufpr.br; renatonagata@gmail.com

\begin{abstract}
Seasonal variation of large medusae abundance and biomass was studied in the North Bay, Santa Catarina, southern Brazil $\left(27^{\circ} 30^{\prime} \mathrm{S}, 48^{\circ} 32^{\prime} \mathrm{W}\right)$, from February to December 2005. Collecting was conducted seasonally with the help of fishing bottom trawl in 30-minute sections (12 in summer, 18 in each of the remaining seasons) in six stations, totaling 66 samples. Eight species were found: the hydrozoans Aequorea sp., Olindias sambaquiensis Müller, 1861, and Rhacostoma atlantica L. Agassiz, 1850; the cubozoans Chiropsalmus quadrumanus (Müller, 1859) and Tamoya haplonema Müller, 1859, and the scyphozoans Aurelia sp., Chrysaora lactea Eschscholtz, 1829 and Lychnorhiza lucerna Haeckel, 1880. Capture rates were low, up to 38 indiv. ha $^{-1}$, and only $\sim 47 \%$ of the samples were positive for jellyfish, comprising 206 individuals. Medusae abundance and species richness clearly changed from one season to another, but did not vary between the sites. Higher species richness ( 7 out of 8 ) and greater abundances were recorded during the fall ( $\sim 60 \%$ and $72 \%$ of all medusae individuals and biomass respectively). Specific frequency of capture varied from 1.5 to $29 \%$ and C. lactea was the only species found in more than $25 \%$ of the samples. The three most common species dominated in different periods of the year: C. lactea during fall (78\% of individuals and $60 \%$ of biomass), $R$. atlantica during winter (90\% of individuals and $17 \%$ of biomass), and O. sambaquiensis in spring (78\% of individuals and $40 \%$ of biomass). Only two individuals were caught during summer, one C. lactea and one $R$. atlantica. The results offer a general picture of the distribution of the macromedusae in the North Bay, but a continuous monitoring is desirable for a more detailed knowledge on the jellyfish dynamics in the Brazilian coastal waters.
\end{abstract}

KEY WORDS. Biomass; Chrysaora lactea; jellyfish; Olindias sambaquiensis, Rhacostoma atlantica.

While most medusae are very small $(<1 \mathrm{~cm})$, some species of Hydrozoa and most species of Cubozoa and Scyphozoa are much larger and may attain several centimeters in diameter (HADDAD 2002). Despite their large size, conspicuous coloration and abundance in coastal waters, macromedusae have been surprisingly overlooked in quantitative studies and considered to be of little ecological importance (e.g. BoLtovskoy 1981: fig. 141, p. 256) until a few decades ago (see HADDOcK 2004). More recently, however, macromedusae have received increasing attention from researchers who realized that these organisms play a crucial role in marine ecosystems and may often be dominant in terms of biomass (e.g. SCHNEIDER \& BEHRENDS 1994, Mianzan \& Guerrero 2000). Very large aggregations are not uncommon (e.g. Kawahara et al. 2006) and may have adverse consequences for a variety of human activities, especially commercial fishing (see NAGATA et al. 2009). In addition to clogging nets and stinging fishermen, these jellyfish may have large negative impacts on zooplankton (e.g. SCHNEIDER \& BEHRENDS 1994), fish eggs and larvae (see Purcell \& Arai 2001).
Large medusae are amongst the least studied marine zooplankton. In Brazil, as in most of South America, research on these animals is still incipient (LOPEs 2007). The population biology of some common Brazilian coastal jellyfishes, for example, has been recently addressed by André C. Morandini (unpubl. data) and by Haddad \& Nogueira Jr (2006). Among the unique records from the shallow waters of the state of Santa Catarina, we highlight those of the German naturalist Fritz Müller (e.g. MülLER, 1859), who described jellyfishes between 1859 and 1883 (see CORRÊA 1966).

The North Bay is limited by the Santa Catarina Island to the east and the mainland to the west (Fig. 1). The bay includes many mangrove areas and has recently become a major sea-farming site providing important income for a community of oysters and mussels growers. Jellyfish are often a nuisance for both human leisure activities and shellfish cultivation.

The last few years have seen growing public awareness and an increase in reported sting events (e.g. Resgalla Jr et al. 2005, Neves et al. 2007), leading to growing media publicity. In 
spite of that, the species of macromedusae in most areas of the Brazilian coast are still unknown. As part of an ongoing study of the jellyfish of southern Brazil (Haddad \& Nogueira JR 2006, Nogueira JR \& HADDAD 2006a, 2008, NAGATA et al. 2009), we have identified the dominant species in the North Bay and estimated their seasonal distribution and abundance in 2005, based on bottom trawl samples. Currently, unprecedented population explosions are being recorded worldwide (e.g. MiLls 2001, KAWAHARA et al. 2006), which may be an indication that major changes in marine ecosystems (PARSONS \& LALLI 2002) are taking place, requiring a continuous estimation of jellyfish abundances over space and time. Within this context, the data presented here can provide important baseline information that is largely absent from the historical literature of most of the South American coastline (but see MiAnZAN 1989a).

\section{MATERIAL AND METHODS}

Two bays connected by a narrow channel and appropriately named North and South Bay exist between the Santa Catarina Island and the mainland (Fig. 1). Several rivers from the Serra do Mar mountain range flow into the bays in small estuaries with mangroves, salt marshes, and sandy beaches. The regional climate is subtropical humid with no characteristic "dry" season but with less rainfall from April to September (Cruz 1998). The depth in the North Bay generally varies from 0-6 m, reaching a maximum of $21 \mathrm{~m}$ in the canal. The northern end of the bay, with the marine Coastal Water as the dominant water mass (MATsuURA 1986, Cruz 1998) is very wide ( 5 km) and has strong shelf influence. Winds and tidal bore are the main physical agents influencing local hydrographic conditions. Locally, micro-tides are asymmetrical in terms of flow between the north and south bay entrances, with the antinode in the middle of the South Bay (MeLo et al. 1997).

Sampling was carried out from February to December 2005, at six locations in the North Bay $\left(27^{\circ} 30^{\prime} \mathrm{S}, 48^{\circ} 32^{\prime} \mathrm{W}\right.$, Fig. 1) as follow: Summer (17 Feb, 5 Mar), Fall (7 May, 28 May and 4 Jun), Winter (6 Aug, 12 Aug and 3 Sept) and Spring (22 Nov, 28 Nov and 3 Dec), totaling 66 hauls. Medusae were collected at all six locations by 30-minute shrimp bottom trawls from a small fishing vessel. Sub superficial $(\sim 1.5-2.0 \mathrm{~m})$ sea water temperature and salinity were measured at the time the samples were taken with a Horiba U-10 multi-parameter water quality meter. Nets were 8.6 $\mathrm{x} 1.8 \mathrm{~m}$, with $2.5 \mathrm{~cm}$ mesh size at the cod-end and $4.0 \mathrm{~cm}$ at the mouth. The netting route was recorded, from which the area included in the netting was estimated and varied from 6626 to 15605 $\mathrm{m}^{2}$ (mean $\left.\pm 95 \% \mathrm{CI}, 10643 \pm 371.4\right)$. Medusae density was then estimated as the number of individuals per hectare $\left(\mathrm{n} \mathrm{ha}^{-1}\right)$.

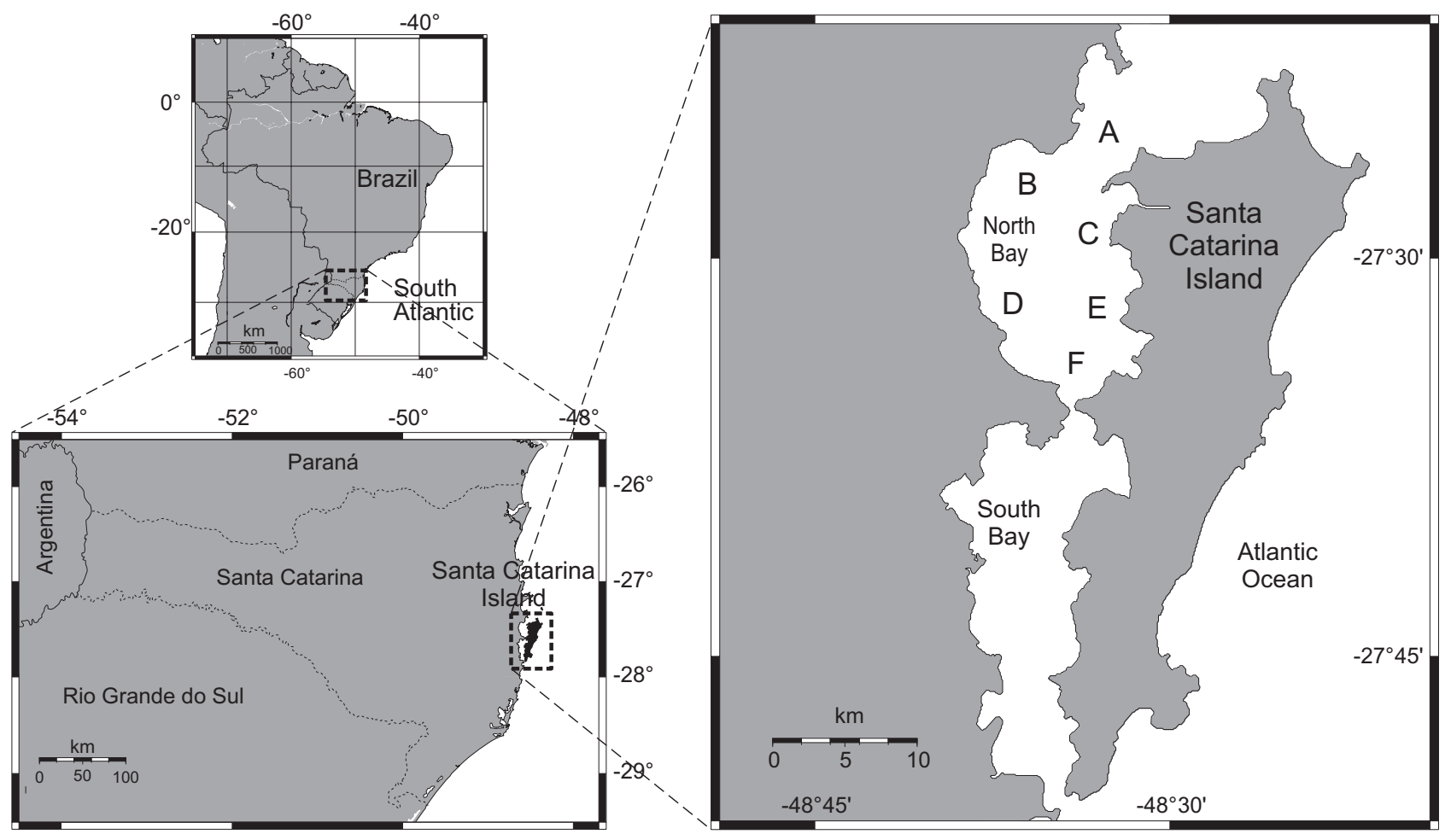

Figure 1. Map showing in detail the North Bay, with letters A through F indicating sampling stations. 
Medusae were sorted on the boat and preserved in $4 \%$ formaldehyde solution in local seawater. In the laboratory, medusae were identified and the umbrellar diameter was measured. Exumbrellar height of the cubomedusans was also measured as the distance between the apex of the exumbrella and its marginal junction with velarium. Reference material is deposited in the Cnidaria Collection, Department of Zoology of the Federal University of Paraná (Dzoo-Cn - 228 to 234).

Biomass (wet weight) was estimated from the measurements, following equations given by NOGUEIRA JR \& HADDAD (2006b) for each species: $\mathrm{W}=0.087 \mathrm{H}^{2.822}$ - Tamoya haplonema Müller, $1859 ; \mathrm{W}=0.1152 \mathrm{D}^{2.83}$ - Chiropsalmus quadrumanus (Müller, 1859); $\mathrm{W}=0.07 \mathrm{D}^{3.028}-$ Chrysaora lactea Eschscholtz, 1829; $\mathrm{W}=0.1266$ $\mathrm{D}^{2.95}$ - Lychnorhiza lucerna Haeckel, 1880; W $=0.1506 \mathrm{D}^{2.37}$ Olindias sambaquiensis Müller, 1861. Where $\mathrm{W}$ is wet weight $(\mathrm{g})$, $\mathrm{D}$ is umbrella diameter $(\mathrm{cm}), \mathrm{H}$ is umbrella height $(\mathrm{cm})$ and the exponent was calculated previously by regression.

Similarly, Rhacostoma atlantica L. Agassiz, 1850 biomass was calculated as $\mathrm{W}=0.4014 \mathrm{D}^{2.0123}$. This regression was based on measurements of 26 fresh caught individuals in the State of
Paraná coast and diameter explained $90 \%$ of the variation in biomass $\left(r^{2}=0.9035\right)$. As no equation of diameter-weight conversion was found for south Atlantic populations of Aurelia spp., specimens fixed for 20 days were weighted after washing and removing excess of water with blotting paper.

Seasonal and spatial changes in the number of species hauled were tested with analysis of variance (ANOVA), after application of normal probability and variance homogeneity tests (SoKAl \& Rohlf 1995) and significance was considered $\mathrm{p}<0.05$.

\section{RESULTS}

All environmental variables differed between seasons (Figs 2 and 3): water temperature varied from 17.5 to $26.0^{\circ} \mathrm{C}$ (Summer mean $=25.6^{\circ} \mathrm{C}$, Winter mean $=19.5^{\circ} \mathrm{C}$ ); salinity was lowest during winter (29.3-35.6\%o) and varied little from $35 \%$ in other seasons, with a maximum of $37.8 \%$ in the fall. Temperature and salinity did not change among stations, regardless of whether the entire data set was analyzed as a whole (Figs 4 and 5), or separated by seasons (not shown).
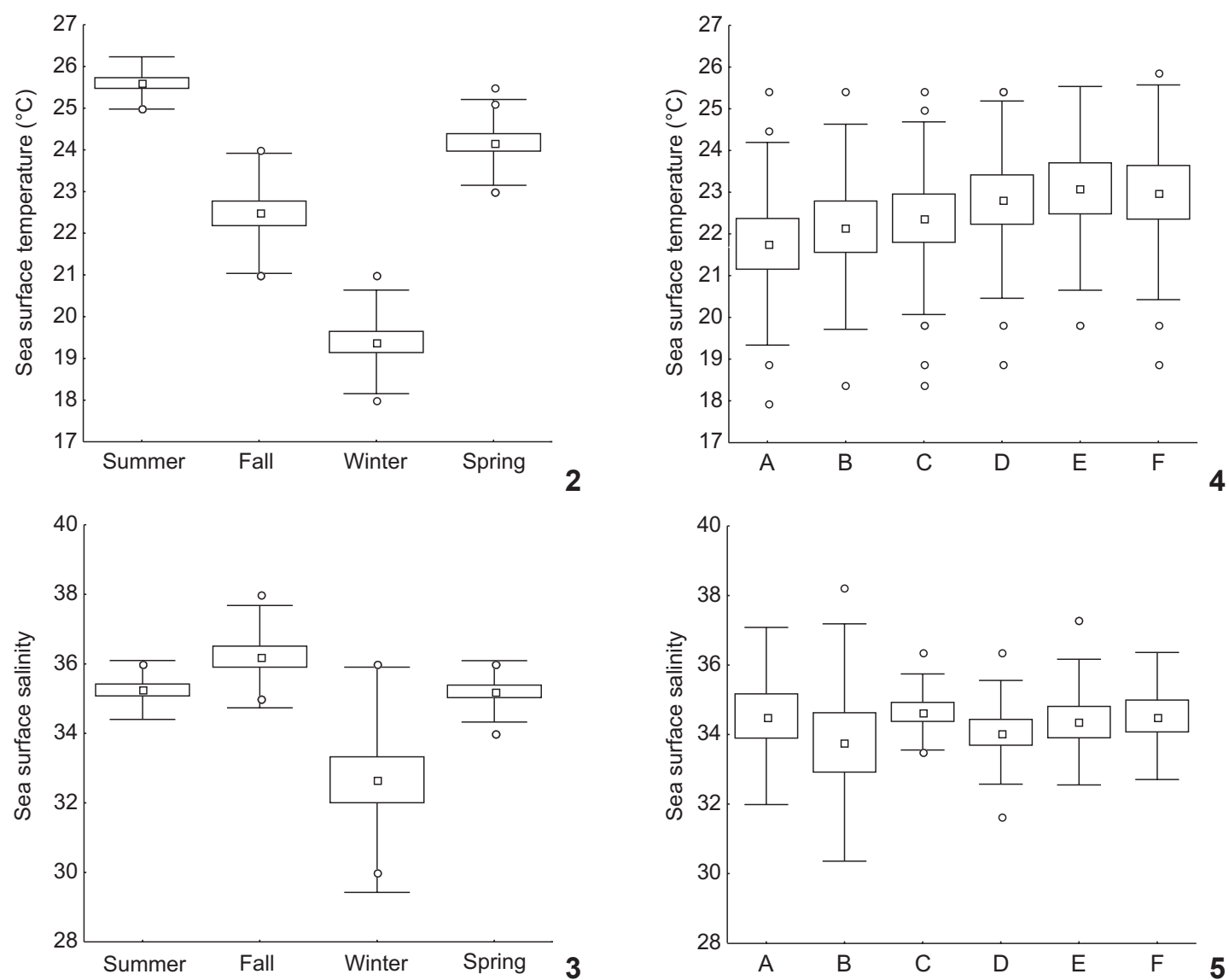

Figures $2-5$. Seasonal $(2,3)$ and spatial $(4,5)$ variation of sea water surface temperature $(2,4)$ and salinity $(3,5)$ in the North Bay, from February to December 2005.

ZOOLOGIA 27 (3): 377-386, June, 2010 
Medusae were gathered in $47 \%$ of the samples, comprising 206 individuals of eight species: three Hydrozoa, two Cubozoa and three Scyphozoa (Tab. I). Frequency of capture was low for all species: $1-29 \%$ of the hauls. Only the scyphomedusa C. lactea (Pelagiidae) was collected in $>25 \%$ of the samples. This species, along with the hydromedusae $R$. atlantica (Aequoreidae) and $O$. sambaquiensis (Olindiidae) comprised $88 \%$ of all jellyfish collected. Chrysaora lactea also accounted for the greatest medusae biomass (45.5\%), followed by L. lucerna (Lychnorhizidae, 27\%) and Aurelia sp. (Ulmaridae, 11\%), both less numerous but with very large individuals (Tab. I).

Mean sizes and ranges of all jellyfishes are shown in table I and histograms of size classes for each species were plotted per sample day (Fig. 6). Despite the relatively few captures by size class of each species, size classes changed over time. For example, in March, only one young (35 mm) C. lactea specimen was captured, while two months later, most of the individuals were larger than $60 \mathrm{~mm}$ in diameter, with voluminous, mature gonads. From the first to the second spring samples, the size of $O$. sambaquiensis changed from $31-40 \mathrm{~mm}$ to the $41-50 \mathrm{~mm}$, indicating a $28 \%$ increase in bell diameter in a few days. Modal sizes of $R$. atlantica also changed during winter (Fig. 6).
The number of species was low (0-3) in all samples, with the highest species richness in fall (ANOVA, $\mathrm{F}(3,62)=6.2$, $\mathrm{p}<0.05$, Fig. 7), when seven out of the eight species were collected (Aequorea sp. - appeared only in winter). Species richness was independent from collecting location (ANOVA, F(5, $60)=1.1, p=0.35$, Fig. 8).

Medusae abundance and species richness clearly changed from one season to another (Figs 7-12). The greatest number of captures was in fall, when jellyfishes appeared in $67 \%$ of the samples, representing $\sim 60 \%$ of the individuals and $72 \%$ of the total biomass. Also during fall, density varied from $\sim 2$ to 15 individuals ha- ${ }^{-1}$ and $\sim 60-995 \mathrm{~g} \mathrm{ha}^{-1}$, with one sample reaching the maximum of 38 individuals ha-1 or $1515 \mathrm{~g} \mathrm{ha}^{-1}$ (Fig. 9). Chrysaora lactea, captured in $61 \%$ of the fall samples, and corresponding to $\sim 78 \%$ of the individuals and $\sim 60 \%$ of the biomass, was the dominant species. Most medusae collected in winter were caught on August 12 ( $<1-6.5$ indiv ha-1, Figs 9 and 11). In winter, $R$. atlantica totalized $>90 \%$ of the individuals but only $\sim 17 \%$ of the biomass (Fig. 12). Biomass was dominated $(\sim 78 \%)$ by a few large $(20-23 \mathrm{~cm})$ L. lucerna taken at a single station ( 1 indiv ha ${ }^{-1}$ or $\left.\sim 1300 \mathrm{~g} \mathrm{ha}^{-1}\right)$. Spring captures were abundant at only stations A and B, with 14-15 indiv. ha ${ }^{-1}$ (Fig.

Table I. Classification and species list of the macromedusae found in North Bay, Florianópolis, Brazil, during 2005. (FO) Frequency of occurrence (\%) in 66 samples, $(\mathrm{N})$ number of specimens. Sizes are the range or the values for species with few individuals, mean value and $95 \%$ confidence interval are in parenthesis.

\begin{tabular}{|c|c|c|c|c|c|}
\hline \multirow{2}{*}{ Taxa } & \multirow{2}{*}{ FO (\%) } & \multirow{2}{*}{$\mathrm{N}$} & \multirow{2}{*}{ Biomass (\%) } & \multicolumn{2}{|c|}{ Size $(\mathrm{mm})$} \\
\hline & & & & Diameter & Height \\
\hline \multicolumn{6}{|l|}{ Hydrozoa } \\
\hline \multicolumn{6}{|l|}{ Aequoreidae } \\
\hline Aequorea sp. & 1.51 & 2 & 0.07 & 15 and 33 & \\
\hline Rhacostoma atlantica & 16.67 & 41 & 4.05 & $15-57(42 \pm 2)$ & \\
\hline \multicolumn{6}{|l|}{ Olindiidae } \\
\hline Olindias sambaquiensis & 15.15 & 36 & 2.56 & $25-70(43 \pm 3.8)$ & \\
\hline \multicolumn{6}{|l|}{ Cubozoa } \\
\hline \multicolumn{6}{|l|}{ Carybdeidae } \\
\hline Tamoya haplonema & 6.06 & 9 & 7.37 & $30-95(71 \pm 18)$ & $35-140(94 \pm 23)$ \\
\hline \multicolumn{6}{|l|}{ Chirodropidae } \\
\hline Chiropsalmus quadrumanus & 1.51 & 1 & 1.22 & 107 & 76 \\
\hline \multicolumn{6}{|l|}{ Scyphozoa } \\
\hline \multicolumn{6}{|l|}{ Ulmaridae } \\
\hline Aurelia sp. & 1.51 & 3 & 11.4 & 165,170 and 170 & \\
\hline \multicolumn{6}{|l|}{ Pelagiidae } \\
\hline Chrysaora lactea & 28.79 & 104 & 45.56 & $20-125(69 \pm 4.6)$ & \\
\hline \multicolumn{6}{|l|}{ Lychnorhizidae } \\
\hline Lychnorhiza lucerna & 12.12 & 10 & 27.76 & $26-230(90 \pm 39)$ & \\
\hline Total & 46.97 & 206 & $7714.84 \mathrm{~g}$ & & \\
\hline
\end{tabular}

ZOOLOGIA 27 (3): 377-386, June, 2010 

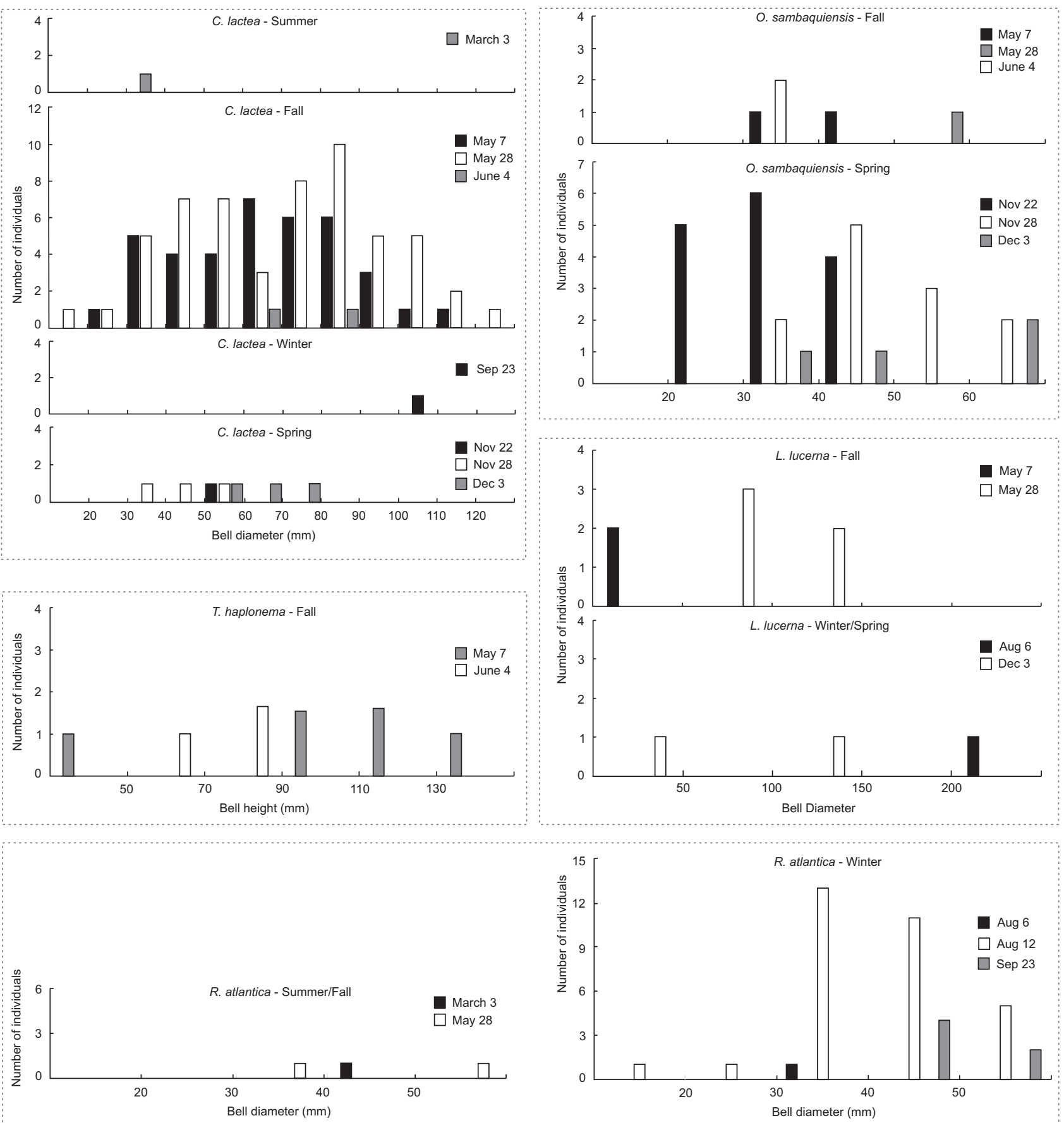

Figure 6. Size (umbrellar diameter or height) distribution of macromedusae from North Bay during 2005.

9), at which time the hydromedusa O. sambaquiensis was dominant (77\% of individuals and $40 \%$ of biomass, Fig. 11). During summer, two trawls included one medusa each, C. lactea and R. atlantica.

\section{DISCUSSION}

The assemblage of large medusae in the North Bay is relatively species rich, with the presence of most species commonly found in southern and southeastern Brazilian coastal waters 

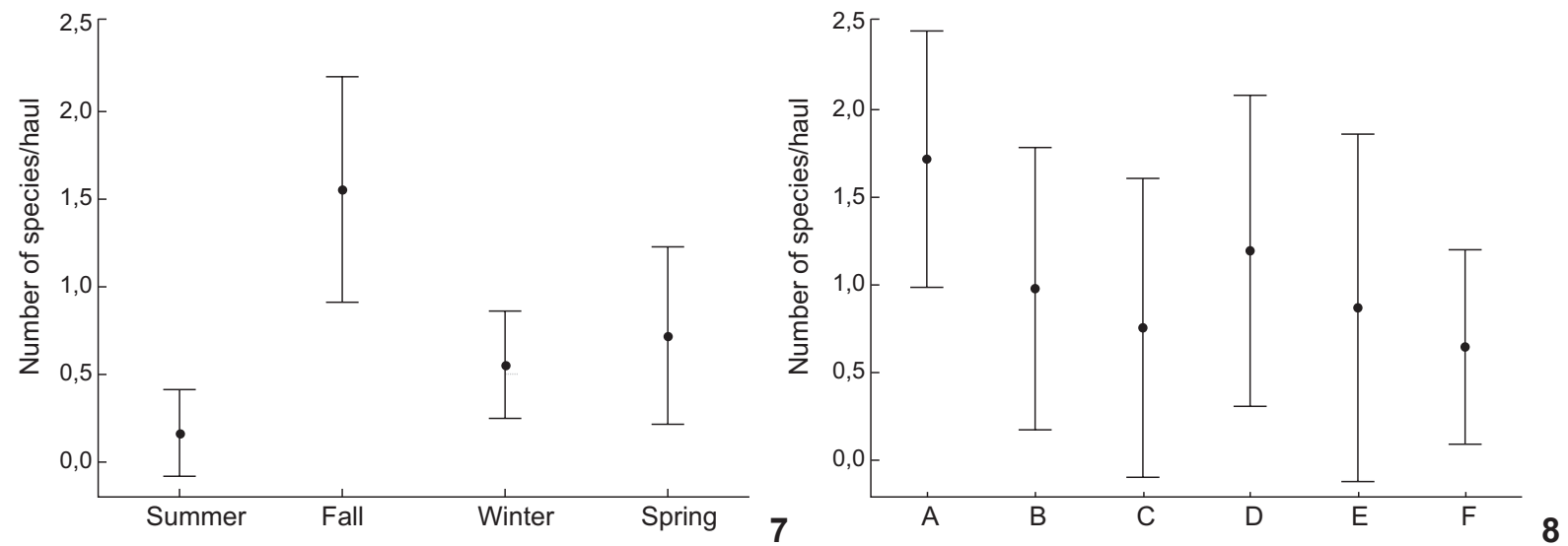

Figures 7-8. Mean seasonal (7) and spatial (8) variation in the number of species of macromedusae per sample in the North Bay during 2005. Circles are mean values and bars indicate the $95 \%$ confidence interval.
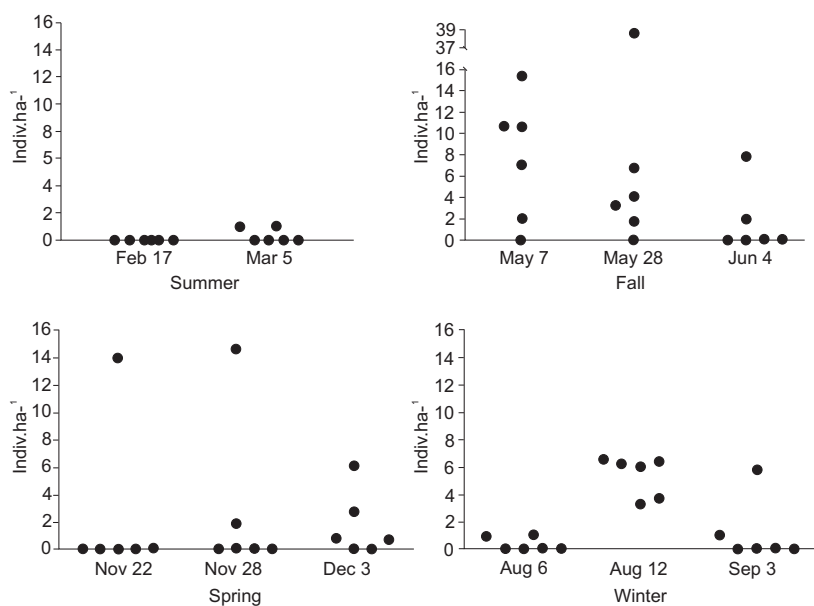

Figure 9. Temporal distribution of estimated macromedusae density in North Bay during 2005.

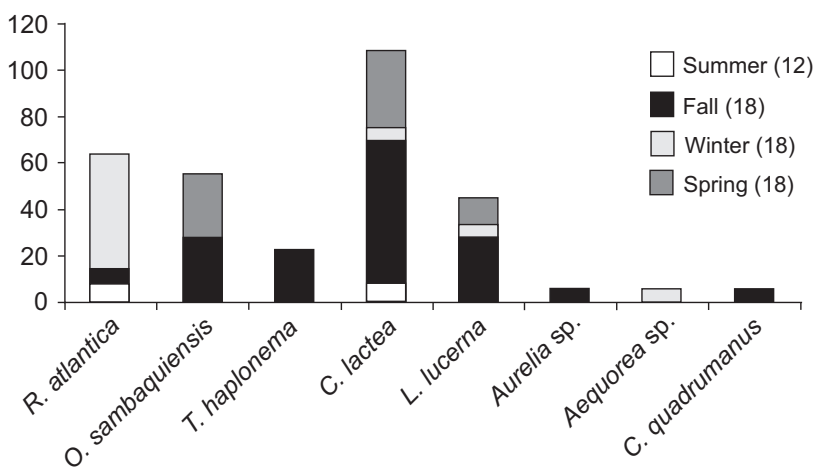

Figure 10. Seasonal variation in frequency of capture (\%) for each jellyfish species in North Bay during 2005. Number in parenthesis are the number of trawls performed on each season.
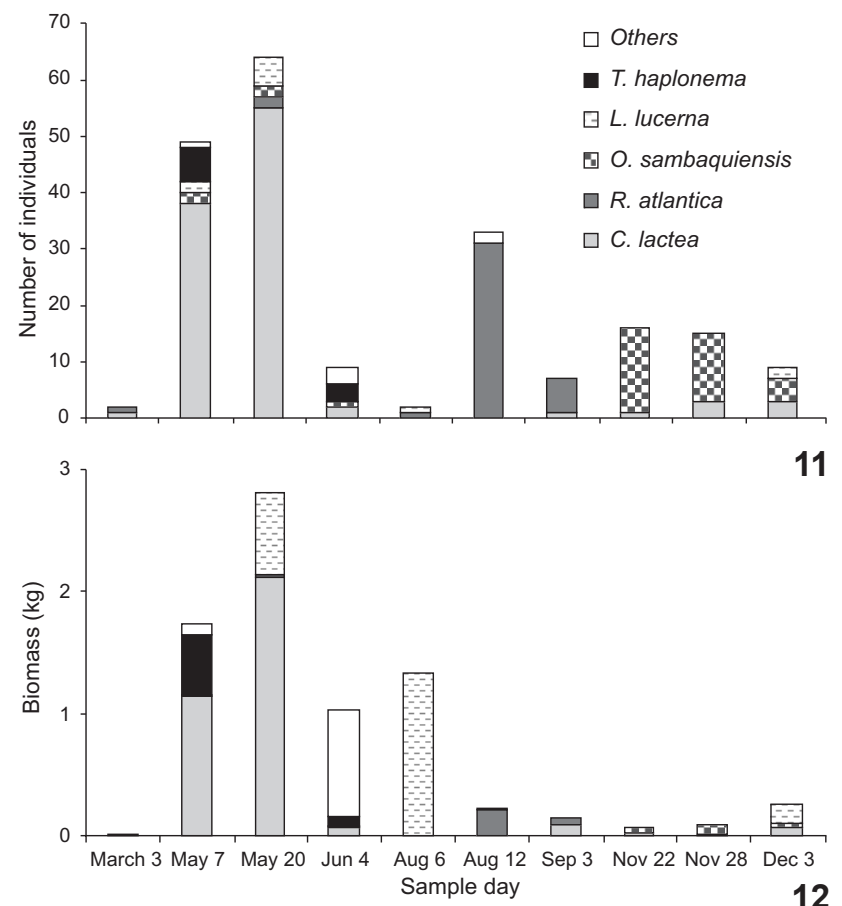

12

Figures 11-12. Contribution of each species to jellyfish abundance (11) and biomass (12), per sample day at North Bay during 2005.

(Vannucci 1951, 1954, Silveira \& Cornelius 2000, Morandini et al. 2005, Nogueira JR \& Haddad 2006a). Of the large medusae reported by Fritz Müller (Müller 1859, 1883, see CorRÊA 1966), the scyphozoan Drymonema dalmatinum Haeckel, 1880 (Cyaneidae) was the only species not recorded by us. While there is a known resident population off the coast of Argentina (Mianzan 1989a, b), this species is rarely found in Brazilian waters (Morandini et al. 2005). 
The dominant jellyfish in the North Bay was C. lactea, one of the most common and abundant Scyphozoa in the Brazilian coastal waters (Silveira \& Cornelius 2000). This species occurred throughout the year (with the majority collected in fall), comprising $45 \%$ of the biomass and $50 \%$ of the individuals sampled in the North Bay. Jellyfishes of Chrysaora Péron \& Lesueur, 1810 are important and often abundant components of coastal systems, including C. quinquecirrha (Desor, 1848) in the Chesapeake Bay (USA) (CARgo \& Schultz 1966, Cargo \& King 1990) and Gulf of Mexico (Graham 2001), C. lactea in Brazil (Morandini et al. 2005, Nogueira Jr \& Haddad 2006a, this study), C. hysoscella (Linnaeus, 1767) in Great Britain (RusselL 1970) and Namibia (Buecher et al. 2001) and C. plocamia (Lesson, 1830) in northern Chile (VEGA \& OGALDE 2008).

Other seasonally abundant species in the North Bay are the hydromedusae O. sambaquiensis and R. atlantica. The former is found from São Paulo to Argentina; it is well-known for causing skin irritation and is often very abundant (VANNUCCI 1951, Zamponi \& Facal 1987, Mianzan \& Guerrero 2000, Nagata et al. 2009). The latter ( $R$. atlantica), noted since the 1970s (Moreira 1975) in the southwestern Atlantic Ocean, was recorded in São Paulo and southern coastal Brazil (NAvas-Pereira 1981, Goy 1979, Nogueira Jr \& Haddad 2006a). The species is also found in large numbers stranded on some beaches of Florianópolis (Nogueira Jr pers. obs.) and may dominate macroplanktonic biomass during the Spring-Summer coastal upwelling near Cape Santa Marta Grande, Santa Catarina (MianZAn \& Guerrero 2000). Apparently, its abundance is associated with surface water temperatures of $20-21^{\circ} \mathrm{C}$, which is near the mean winter temperature in our study area $\left(19.5^{\circ} \mathrm{C}\right)$, when most individuals were captured.

Tamoya haplonema, one of the least abundant species in this study, is considered rare along the Brazilian coast (MORANDINI et al. 2005). Nonetheless, in the fall, this species was one of the most frequently caught, being present in $25 \%$ of the samples and comprising $10 \%$ of the macromedusae abundance (both in number and biomass). While not abundant, it is recurrently found in coastal waters in the southwestern Atlantic, mostly during summer and fall, often causing accidents with swimmers and fishermen (MÜlLER 1859, CORRÊA 1966, PASTORINo 2001, Haddad Jr et al. 2002, 2005, Morandini et al. 2005, Nogueira JR \& Haddad 2006a, 2008, Nagata et al. 2009).

The scarcity of $C$. quadrumanus and particularly of $L$. lucerna is worth mentioning, since these jellyfishes are usually common and abundant in coastal waters of southeastern and southern Brazil (VANnucCi 1954, MoRAndini et al. 2005, NAGATA et al. 2009). The two specimens of Aequorea Perón \& Lesueur, 1810 were not identified to species level because their umbrellar margin was damaged and few intact radial canals remained. However, the shape of the few lasting tentacular bulbs and the absence of excretory pores on them are as in A. forskalea Péron \& Lesueur, 1810 (Boullon 1999), the only species of the genus recorded in Brazil (MigotTo et al. 2002). The individuals of Aurelia Péron \& Lesueur, 1810 were also not determined to spe- cies due to the current taxonomic confusion in the genus (see Morandini et al. 2005). The medusae of these two genera are seldom reported from Brazil and are also rare in the North Bay.

The seasonal variability observed in the environmental data is typical of the region, which is strongly affected by the annual temperature cycle (Cruz 1998, Castro et al. 2005). The absence of spatial differences in environmental variables reflects the dynamism of the waters within the bay that result from the tidal circulation patterns (Melo et al. 1997). This is consistent with the abundance patterns observed for the most common jellyfish species, C. lactea, O. sambaquiensis and $R$. atlantica, which show clear temporal separation. The latter is more common during winter, whereas the remaining ones are more abundant during fall (mostly C. lactea) and spring (mostly O. sambaquiensis). While relatively well known worldwide (e.g. ARAI 1997), large jellyfish seasonality is poorly understood in Brazil as a result of the scarcity of studies on the subject. Similar to what has been observed in the present study, Moreira (1975) noted that $R$. atlantica is common mainly during winter in the coast of São Paulo. In the same region, VANNUCCI (1951) reported $O$. sambaquiensis throughout the year but mostly during winter, and André C. Morandini (unpubl. data), observed that C. lactea was more abundant between late winter and early spring. Both results contrast with our data for the North Bay. The dominance of a species in at least two of the three sampled dates at each season (summer except) denote consistency in the seasonal pattern observed in this study.

Abundance in general was low, with more than half of the hauls retrieved without a single medusa. With the exception of C. lactea, medusae captures seemed accidental (using the criteria of $<25 \%$ of capture frequency following DAJOZ 1972). The low frequency of capture in our data contrasts with other studies that used the same technique in adjacent regions (Vannucci 1951, 1954, Branco \& Verani 2006, Nogueira Jr \& HADDAD 2006a) and may suggest that medusae form occasional aggregations in the North Bay, probably carried by tidal and/or wind driven advection from external adjacent shelf waters. Even though we do not have adequate oceanographic data to evaluate the role of advection, the following factors may support our hypothesis: 1) the low residence time of waters inside North Bay due to tidal-induced circulation (Melo et al. 1997); 2) the high influence of adjacent shelf waters (CRUz 1998), confirmed by the relatively high values of salinities obtained (usually $\geqslant 34 \%$ ).

Estimates of abundance and biomass are indirect methods to examine productivity (OMORI \& IKEDA 1984) and can provide important information for the generation of trophic models. The quantification of large medusae is a notoriously difficult task for a variety of reasons, including their soft structure and large sizes. Additionally, capture in standard plankton nets is also a problem due to the small volume of water that passes through the nets (e.g. Hamner et al. 1975, Mianzan \& Cornelius 1999) and the fact that jellyfish often concentrate in scattered parts of the sampling area. To overcome these difficulties, a 
variety of methods have been used, including large pelagic nets (Hay et al. 1990, Pagès et al. 1996, Mianzan \& Guerrero 2000, Suchman \& BRodeur 2005), individual counts in situ in scuba diving (Zavodnik 1987, Malej 1989), submersibles (e.g. Vinogradv et al. 1985, VereshchaKa \& Vinogradov 1999), underwater videos (Alvarez Colombo et al. 2009), surface counts (Gomez-Aguirre 1980, Pitt \& Kingsford 2003, Doyle et al. 2007), aerial photography (Graham et al. 2003), acoustic (Alvarez Colombo et al. 2003, 2009) and demersal fishing gears (Brodeur et al. 1999, 2002, GrAHAM 2001), used opportunistically in this study to take advantage of material collected by other researchers.

Even though the estimates of density and biomass are coarse (see Brodeur et al. 2002) and a relatively small number of organisms were captured in the present study, the sampling effort and design generated data that indeed shows trends in the macromedusae populations of the North Bay. In summary, the jellyfish community in the North Bay has greater species richness and abundance during the fall when C. lactea is dominant. In winter, $R$. atlantica dominates, though with lower abundance, followed by O. sambaquiensis during the spring. Considering the tremendous annual variation that is common among marine invertebrates in general, and for macromedusae specifically, we recommend continuous population monitoring over larger temporal and spatial scales to better understand the population dynamics and ecosystem influences of macromedusae in Brazilian coastal waters.

\section{ACKNOWLEDGEMENTS}

We thank Fábio Daura Jorge and Leonardo Wedekin for providing the material studied; CAPES and CNPq for financial support; André C. Morandini (IB-USP) and two anonymous reviewers for critical reading and suggestions that greatly improved the original text.

\section{LITERATURE CITED}

Alvarez Colombo, G.; H.W. Mianzan \& A. Madirolas. 2003. Acoustic characterization of gelatinous-plankton aggrgations: four case studies from the Argentine continental-shelf. ICES Journal of Marine Science 60: 650-657. doi:10.1016/S10543139(03)00051-1.

Alvarez Colombo, G.; A. Benovic; A. Malej; D. Lucic; T. Makovec; V. Onofri; M. Acha; A. Madirolas \& H. Mianzan. 2009. Acoustic survey of a jellyfish-dominated ecosystem (Mljet Island, Croatia). Hydrobiologia 616: 99-111. doi: 10.1007/s10750008-9587-6.

AraI, M.N. 1997. A functional Biology of Scyphozoa. London, Chapman \& Hall, 316p.

Boltovskoy, D. 1981. Atlas del zooplancton el Atlântico sudoccidental y metodos de trabajos con el zooplancton mariño. Mar del Plata, INIDEP, 936p.

Bouillon, J. 1999. Hydromedusae, p. 424-512. In: D. Boltovskoy (Ed.). South Atlantic Zooplankton. Leiden, Backhuys
Publishers, vol. 1, 868p.

Branco, J.O. \& J.R. Verani. 2006. Pesca do camarão sete-barbas e sua fauna acompanhante, na Armação do Itapocoroy, Penha, SC, p. 153-170. In: J.O. Branco \& A.W.C. Marenzi (Eds). Bases ecológicas para um desenvolvimento sustentável: estudos de caso em Penha, SC. Itajaí, Editora Univalli, 291p.

Brodeur, R.D.; C.E. Mills; J.E. Overland; G. Walters \& J.D. Schumacher. 1999. Evidence for a substantial increse in gelatinous zooplankton in the Bering Sea, with possible links to climate change. Fisheries Oceanography 8 (4): 296-306.

Brodeur, R.; H. SugISAKI \& G.L. HunT JR. 2002. Increases in jellyfish biomass in the Bering Sea: implications for the ecosystem. Marine Ecology Progress Series 233: 89-103. doi:10.3354/ meps233089.

Buecher, E.; C. Sparks; A. Brierley; H. Boyer \& M.J. Gibbons. 2001. Biometry and size distribution of Chrysaora hysoscella (Cnidaria, Scyphozoa) and Aequorea aequorea (Cnidaria, Hydrozoa) off Namibia with notes on their parasite Hyperia medusarum. Journal of Plankton Research 23 (10): 10731080. doi:10.1093/plankt/23.10.1073.

Cargo, D.G. \& L.P. Schultz. 1966. Notes on the biology of the sea nettle, Chrysaora quinquecirrha, in the Chesapeake Bay. Chesapeake Science 7: 95-100. doi: 10.2307/1351129.

CARGO, D.G. \& D.R. KING. 1990. Forecasting the abundance of the Sea Nettle Chrysaora quiquecirrha, in the Chesapeake Bay. Estuaries 13(4): 486-491. doi: 10.2307/1351793.

Castro, B.M.; F.P. Brandini; A.M. Pires-Vanin \& L.B. Miranda. 2005. Multidisciplinary oceanographic processes on the Western Atlantic continental shelf between $4^{\circ} \mathrm{N}$ and $34^{\circ} \mathrm{S}$, p. 259293. In: R. Robinson \& K.H. Brink (Eds). The Sea. Harvard College, vol. 14, 840p.

CorrêA, D.D. 1966. Os celenterados estudados por Fritz Muller. Ciência e Cultura 18 (4): 382-383.

Cruz, O. 1998. A Ilha de Santa Catarina e o continente próximo. Um estudo de geomorfologia costeira. Florianópolis, Editora da Universidade Federal de Santa Catarina, 280p.

DAJOz, R. 1972. Ecologia Geral. Petropolis, Vozes, $2^{\text {nd }}$ ed., 474p.

Doyle, T.; J.D.R. Houghton; S.M. BuckLey; G.C. Hays \& J. Davenport. 2007. The broad-scale distribution of five jellyfish species across a temperate coastal environment. Hydrobiologia 579: 29-39. doi: 10.1007/s10750-006-0362-2.

Gomez-Aguirre, S. 1980. Variación estacional de grandes medusas (Scyphozoa) en un sistema de lagunas costeras del sur del golfo de México (1977/1978). Boletim do Instituto Oceanográfico 29 (2): 183-185.

Goy, J. 1979. Campagne de la Calypso au large des côtes atlantiques de l’Amérique du sud (1961-1962). Méduses. Résultats Scientifiques des Campagnes de la Calypso 11: 263-296.

GrAHAM, W.M. 2001. Numerical increases and distributional shifts of Chrysaora quinquecirrha (Desor) and Aurelia aurita (Linné) (Cnidaria: Scyphozoa) in the northern Gulf of Mexico. Hydrobiologia 451: 97-111. doi: 10.1023/A:1011844208119. 
Graham, W.M.; D.L. Martin; D.L. Felder; V.L. Asper \& H.M. Perry. 2003. Ecological and economic implications of a tropical jellyfish invader in the Gulf of Mexico. Biological Invasions 5: 53-69. doi: 10.1023/A:1024046707234.

HADDAD M.A. 2002. Cnidaria. p. 25-50. In: C.S. Ribeiro-Costa \& R.M. RochA (Eds.). Invertebrados: manual de aulas práticas. Ribeirão Preto, Editora Holos, 226p.

Haddad, M.A. \& M. Nogueira JR. 2006. Reappearance and seasonality of Phyllorhiza punctata von Lendenfeld (Cnidaria; Scyphozoa; Rhizostomeae) medusae in southern Brazil. Revista Brasileira de Zoologia 23 (3): 824-831. doi: 10.1590/ S0101-81752006000300030.

Haddad JR, V.; F.L. Silveira; J.L.C. Cardoso \& A.C. Morandini. 2002. A Report of 49 Cases of Cnidarian envenoming from southeastern Brazilian Coastal Waters. Toxicon 40: 14451450. doi: 10.1016/S0041-0101(02)00162-9.

Haddad Jr, V.; M.R. Rosa \& J.C. Lastória. 2005. Acidentes por águas-vivas e caravelas (cnidários): atualizações em epdemiologia, aspectos clínicos e terapêutica. Diganóstico e Tratamento 10 (1): 35-37.

HADDock, S.H.D. 2004. A golden age of gelata: past and future research on planktonic ctenophores and cnidarians. Hydrobiologia 530/531: 549-556. doi: 10.1007/S10750004-2653-9.

Hamner, W.M.; L.P. Madin; A.L. Alldredge; R.W. Gilmer \& P.P. Hamner. 1975. Underwater observation of gelatinous zooplankton: Sampling problems, feeding biology, and behavior. Limnology and Oceanography 20 (6): 907-917.

HaY, S.J.; J.R.G. Hislop \& A.M. Shanks. 1990. North sea Scyphomedusae: summer distribution, estimated biomass and significance particularly for o-group gadoid fish. Netherlands Journal of Sea Research 25 (1/2): 113-130.

Kanahara, M.; S.-I. Uye; K. Ohtsu \& H. Iizumi. 2006. Unusual population explosion of the giant jellyfish Nemopilema nomurai (Scyphozoa: Rhizostomeae) in East Asian waters. Marine Ecology Progress Series 307: 161-173. doi: 10.3354"meps307161.

LOPES, R.M. 2007. Marine zooplankton studies in Brazil - a brief evaluation and perspectives. Anais da Academia Brasileira de Ciências 79 (3): 369-379. doi: 10.1590"S000137652007000300002.

MALej, A. 1989. Behaviour and trophic ecology of the jellyfish Pelagia noctiluca (Forsskal, 1775). Journal of Experimental Marine Biology and Ecology 126 (3): 259-270. doi:10.1016/ 0022-0981(89)90191-3.

Matsuura, Y. 1986. Contribuição ao estudo da estrutura oceanográfica da região sudeste entre Cabo Frio (RJ) e Cabo de Santa Marta Grande (SC). Ciência e Cultura 38 (8): 1439. 1450 .

Melo, E.; R.P. Martins \& D. Franco. 1997. Standing wave tide at Florianópolis Bay (Brazil) and its influence on bay pollution. Proceedings of BORDOMER 97 - Coastal Environment Management and Conservation 2: 143-151.
Mianzan, H.M. 1989a. Las medusa Scyphozoa de la Bahía Blanca, Argentina. Boletim do Instituto Oceanográfico 37 (1): 29-32.

MianZAN, H.M. 1989b. Sistemática y zoogeografía de Scyphomedusae en águas neríticas argentinas. Investigaciones Marinas CICIMAR 4 (1): 15-34.

Mianzan, H.M. \& P.F.S. Cornelius. 1999. Scyphomedusae and Cubomedusae, p. 513-559. In: D. Boltovskoy (Ed.). South Atlantic Zooplankton. Leiden, Backhuys Publishers, vol. $1,868 \mathrm{p}$.

Mianzan, H.W. \& R.A. Guerrero. 2000. Environmental patterns and biomass distribution of gelatinous macrozooplankton. Three study cases in the South-western Atlantic Ocean. Scientia Marina 64 (Supll. 1): 215-224. doi: 10.3989/ scimar.2000.64s1215.

Milts, C.E. 2001. Jellyfish blooms: are populations increasing globally in response to changing climatic conditions? Hydrobiologia 451: 55-65. doi: 10.1023/A:1011888006302.

Migotto, A.E.; A.C. Marques; A.C. Morandini \& F.L. Silveira. 2002. Checklist of the Cnidaria Medusozoa of Brazil. Biota Neotropica 2 (1): 1-30.

Morandini, A.C.; D. Ascher; S.N. Stampar \& J.F.V. Ferreira. 2005. Cubozoa e Scyphozoa (Cnidaria: Medusozoa) de águas costeiras do Brasil. Iheringia, Série Zoologia 95 (3): 281-294. doi: 10.1590"S0073-47212005000300008.

Moreira, G.S. 1975. Sobre duas Leptomedusae do litoral do estado de São Paulo. Ciência Cultura 27 (5): 556-558.

Müller, F. 1859. Zwei neue Quallen von Santa Catharina. Tamoya haplonema und quadrumana. Abhandlungen der Naturforschenden Gesellschaft in Halle 5: 1-12.

Müller, F. 1883. Drymonema an der Küste von Brasilien. Zoologische Anzeiger 6: 220-222.

Nagata, R.M.; M.A. Haddad \& M. Nogueira Jr. 2009. The nuisance of medusae (Cnidaria, Medusozoa) to shrimp trawls in central part of southern Brazilian Bight, from the perspective of artisanal fishermen. Pan-American Journal of Aquatic Sciences 4 (3): 312-325.

Navas-Pereira, D. 1981. Distribuição das hidromedusas na região da plataforma continental do Rio Grande do Sul. Seminários de Biologia Marinha, Academia Brasileira de Ciências, p. 221-276.

Neves, R.F.; F.D Amaral \& A.Q. Steiner. 2007. Levantamento de registros dos acidentes com cnidários em algumas praias do litoral de Pernambuco (Brasil). Ciência \& Saúde Coletiva 12 (1): 231-237. doi: 10.1590/S1413-81232007000100026.

Nogueira JR, M. \& M.A. HaddAd. 2006a. Macromedusae (Cnidaria) fom the Paraná coast, Southern Brazil. Journal of Coastal Research SI 39: 1161-1164.

Nogueira Jr, M. \& M.A. Haddad. 2006b. Relações de tamanho e peso das grandes medusas (Cnidaria) do litoral do Paraná, Sul do Brasil. Revista Brasileira de Zoologia 23 (4): 12311234. doi: 10.1590"S0101-81752006000400033.

Nogueira JR, M. \& M.A. Haddad. 2008. The diet of cubomedusae (Cnidaria, Cubozoa) in southern Brazil. Brazilian Journal 
Oceanography 56 (3): 157-168. doi: 10.1590"S167987592008000300001.

OMORI, M. \& T. IKEDA. 1984. Methods in Marine Zooplankton Ecology. Malabar, Krieger Publishing Company, 332p.

Pagès, F.; M.G. White \& P.G. Roadhouse. 1996. Abundance of gelatinous carnivores in the nekton community of the Antartic Polar Frontal Zone in summer 1994. Marine Ecology Progress Series 141: 139-147. doi:10.3354/meps141139.

Parsons, T.R. \& C.M. Lalli. 2002. Jellyfish populations explosions: revisiting a hypothesis of possible causes. La Mer 40: 111-121.

Pastorino, G. 2001. New record of the cubomedusa Tamoya haplonema Müller, 1859 (Cnidaria: Scyphozoa) in the south Atlantic. Bulletin of Marine Science 68 (2): 357-360.

PitT, K.A. \& M.J. Kingsford. 2003. Temporal variation in the virgin biomass of the edible jellyfish Catostylus mosaicus. Fisheries Research 63 (3): 303-313. doi:10.1016/S01657836(03)00079-1.

PurCell, J.E. \& M.N. Arai. 2001. Interactions of pelagic cnidarians and ctenophores with fish: a review. Hydrobiologia 451: 27-44. doi: 10.1023/A:1011883905394.

Resgalla Jr., C.; V.C. Gonçalves \& A.H.F. Klein. 2005. The occurrence of jellyfish stings on the Santa Catarina coast, southern Brazil. Brazilian Journal of Oceanography 53 (3/ 4): 183-186. doi: 10.1590/S1679-87592005000200008.

Russell, F.S. 1970. The Medusae of British Isles: Pelagic Scyphozoa. London, Cambridge University, vol. 2, 284p.

Schneider, G. \& G. Behrends. 1994. Population dynamics and trophic role of Aurelia aurita medusae in the Kiel Bight and western Baltic. ICES Journal of Marine Science 51: 359367. doi:10.1006/jmsc.1994.1038.

Silveira, F.L. \& P.F.S. Cornelius. 2000. Novas observações sobre medusas (Cnidaria, Scyphozoa, Rhizostomeae) no nordeste e no sul do Brasil. Acta Biologica Leopoldensia 22: 9-18.

Sokal, R.R. \& J.F. Rohlf. 1995. Biometry. New York, Freeman, $887 \mathrm{p}$.

Suchman, C.L. \& R.D. Brodeur. 2005. Abundance and distribution of large medusae in surface waters of the northern California Current. Deep-Sea Research II, 52: 51-72. doi: 10.1016/ j.dsr2.2004.09.017.

Vannucci, M. 1951. Distribuição dos Hydrozoa até agora conhecidos nas costas do Brasil. Boletim do Instituto Oceanográfico 2 (1): 105-124.

VannuCCI, M. 1954. Hydrozoa e Scyphozoa existentes no Instituto Oceanográfico. II. Boletim do Instituto Oceanográfico 5 (1-2): 95-149.

Vega, M.A. \& Ogalde, J.P. 2008. First results on qualitative characteristics and biological activity of nematocyst extracts from Chrysaora plocamia (Cnidaria, Scyphozoa). Latin American Journal of Aquatic Research 36 (1): 83-86. doi: 10.3856"vol36-issue1-fulltext-6.

Vereshchaka, A.L. \& G.M. Vinogradov. 1999. Visual observations of the vertical distribution of plankton throughout the water column above Broken Spur vent field, Mid-Atlantic Ridge. Deep-Sea Research I 46 (9): 1615-1632. doi:10.1016/S09670637(99)00018-7.

Vinogradov, M.E.; M.V. Flint \& E.A. Shushrina. 1985. Vertical distribution of mesoplankton in the open area of the Black Sea. Marine Biology 89 (1): 95-107. doi: 10.1007/BF00392881.

Zamponi, M.O. \& O.N. FaCal. 1987. Estudio bioecologico de Olindias sambaquiensis Müller, 1861, em el area de Monte Hermoso. I. Ciclo de vida (Limnomedusae; Olindiidae). Neotropica 33 (90): 119-126.

ZAVODNIK, D. 1987. Spatial aggregations of the swarming jellyfish Pelagia noctiluca (Scyphozoa). Marine Biology 94: 265-269. doi: 10.1007/BF00392939.

Submitted: 06.V.2009; Accepted: 22.III.2010.

Editorial responsibility: Paulo da Cunha Lana 